\title{
Effect of prenatal counselling on compliance and outcomes of teenage pregnancy
}

\author{
F.A. Mersal, ${ }^{1}$ O.M. Esmat ${ }^{7}$ and G.M. Khalil ${ }^{2}$
}

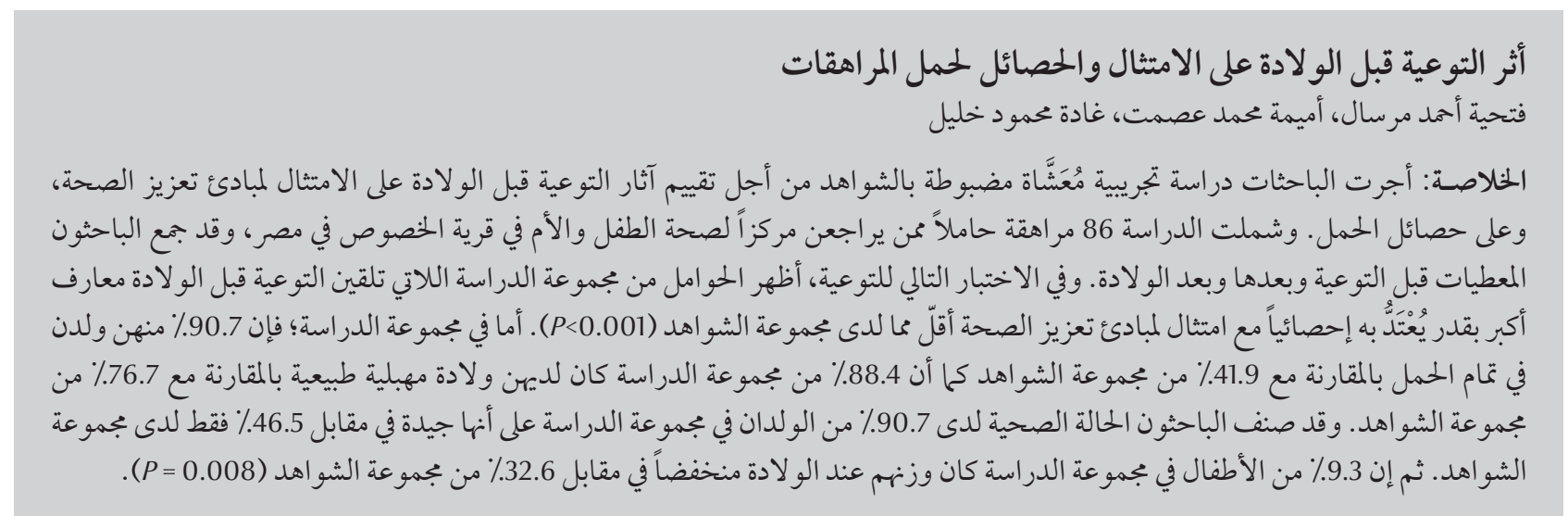

ABSTRACT To evaluate the effect of prenatal counselling on compliance for health promotion and pregnancy outcomes we conducted an experimental randomized control study on a sample of 86 teenage pregnant women attending the maternal and child health centre in Elkhosos village, Egypt. Data were collected pre-counselling, post-counselling and after delivery. At the post test, women in the study (counselling) group showed statistically significantly greater knowledge and compliance of health promotion $(P<0.001)$ than women in the control group. In the study group, $90.7 \%$ were full term at labour compared with $41.9 \%$ in the control group; $88.4 \%$ of the women in the study group had normal vaginal delivery compared with $76.7 \%$ of those in the control group. The health condition in $90.7 \%$ of the study group neonates was classified as good compared with only $46.5 \%$ in the control group. Only $9.3 \%$ of the study group babies had low birth weight compared with $32.6 \%$ of the control group babies $(P=0.008)$.

Effet des conseils prénatals sur l'observance de recommandations et sur l'issue des grossesses d'adolescentes

RÉSUMÉ Afin d'évaluer l'effet des conseils prénatals sur l'observance des recommendations favorisant une bonne santé et sur l'issue des grossesses, nous avons mené une étude contrôlée, randomisée et expérimentale sur un échantillon de 86 adolescentes enceintes consultant au centre de santé maternelle et infantile du village d'Elkhosos (Égypte). Des données ont été recueillies avant et après l'offre de conseils, puis après la naissance. Lors de l'évaluation suivant l'offre de conseils prénatals, les femmes du groupe à l'étude (conseils) montraient des connaissances favorisant une meilleure santé statistiquement plus importantes et étaient plus nombreuses à les appliquer $(P<0,001)$ que les femmes du groupe témoin. Dans le groupe à l'étude, 90,7\% ont mené leur grossesse à terme contre $41,9 \%$ dans le groupe témoin ; $88,4 \%$ des femmes du groupe à l'étude ont accouché par voie basse contre $76,7 \%$ dans le groupe témoin. L'état de santé des nouveau-nés du groupe à l'étude a été jugé satisfaisant pour $90,7 \%$ d'entre eux contre seulement $46,5 \%$ dans le groupe témoin. Seuls $9,3 \%$ des enfants du groupe à l'étude présentaient un faible poids de naissance contre 32,6\% des enfants du groupe témoin ( $P=$ 0,008). 


\section{Introduction}

Teenage pregnancy is a worldwide phenomenon affecting both developed and developing countries [1]. About 15 million women/girls aged under 20 years give birth each year, roughly $11 \%$ of all births worldwide. The vast majority of these births, almost 95\%, occur in developing countries [2]. In Egypt, by the age of 19 years, one-fifth of married women have already begun childbearing [3].

Adolescent pregnancy is one of the main issues in every health care system since early pregnancy can have harmful implications on girls physical, psychological, economic and social status [4]. A girl who becomes pregnant while still a teenager faces a multitude of problems: she faces motherhood prematurely, usually before her own maturation has been completed [5]. Potentially severe medical complications place both the mother and infant at risk for illness and death.

Teenage mothers often have poor antenatal care as they do not always attend their antenatal appointments; they tend to deliver more low birthweight babies, premature babies and babies who die during the first year of their life [4]; infant mortality and morbidity rates are higher for infants born to teenage mothers than infants born to older women [6].

Education is a key aspect of nursing care provided during the prenatal period. Appropriate education may result in positive outcomes for the mother and her infant. $[7,8]$. To achieve healthy outcomes, pregnant women must be offered relevant health education and health promotion information throughout their pregnancy [9]. Pregnant adolescents who receive little or no prenatal care have higher rates of complications than those who receive adequate care [10].

Prenatal health education is an important strategy for reducing prenatal health disparities for women who are members of a vulnerable population [11]. Nurses and health care providers are in a position of being able to provide counsel and communication to the clients with a multitude of problems. They are in a unique position to develop interventions that will impact and enhance patients' ability to adhere to their prescribed regimens [12]. Receiving adequate counselling during pregnancy has an impact on delivering healthy infants and decreases the risk of low birth weight [13]. Patterson et al. reported that women who engage in self-care behaviours, change their diets, rest, exercise, and consume no alcohol or medications seek safe passage for their infants and themselves [14].

The aim of this study was to evaluate the effect of prenatal counselling on teenage pregnancy knowledge, compliance with health promotion in teenage pregnancy and pregnancy outcomes.

\section{Methods}

We conducted this randomized controlled study at Elkhosos, a village in El-Kalubia Governorate, Egypt, with a population of 167055 . This village has 1 maternal and child health centre, affiliated to the Ministry of Health and Population, and this is where our study was carried out.

For the postnatal assessment, however, we visited the homes of the mothers and neonates to collect information on the birth and the outcomes of pregnancy (43 mothers and their babies in the experimental group and 43 in the control group).

\section{Sampling}

All the pregnant teenage women who participated in this study were attending the antenatal clinic in the maternal and child health centre.

Inclusion criteria were: under 20 years of age; primigravida, in second trimester; had not participated in any previous educational programme regarding health promotion; and free from noncommunicable disease (heart disease, diabetes, hypertension).

We invited a total of 103 women to participate in the study; 10 of these women were unwilling to participate for various reasons, including illness and lack of time. We divided the participants into two groups, 47 in the study group and 46 in the control group. However, 4 were excluded from the study group and 3 from the controls owing to incomplete data. The total number of participants was, therefore, 86 teenage pregnant women, 43 in each. The women in the study group were given the education intervention and the women in the control group and had no intervention.

\section{Ethical considerations}

Oral verbal consent to take part in the study was obtained from the teenage pregnant women in our sample. The purpose of the study was explained to the women prior to their consent. They were assured about anonymity, confidentiality of the data and their right to withdraw from the study at any time with no penalty.

\section{Pilot study}

A pilot study was carried out on 5 pregnant teenage women who were not included in the later study. The aim of the pilot study was to test clarity, simplicity and applicability of the study tools.

Data collection was carried out via interviews conducted by the researchers. We used a structured questionnaire covering personal characteristics, knowledge regarding health promotion needs and health promotion activities; a compliance tool (designed by the researchers); and a physical assessment, which covered present health condition, postnatal health condition and physical assessment of the neonate (through home visit 3-6 days after delivery). 


\section{Implementation phase}

Data collection was carried out over 3 days per week during the period September 2008-March 2009. The pre-intervention test was done for 86 pregnant teenagers over a period of 2 months. The implementation phase lasted for 5 months to assess the outcome of the pregnancy. The prenatal counselling programme was designed by the researchers and based on the information obtained from the pre-test study tools and findings from similar research; it was revised and modified according the related literature. The post test was conducted in the $\mathrm{MCH}$ on all participants 3 months after the pre-test. Pregnancy outcome was assessed in the home 3-6 days after delivery.

According to the assessment phase and agreement that was obtained in the first session, counselling was implemented in the maternal and child health room; 3-4 sessions were conducted for each teenage pregnant woman.
Data were revised, coded, and tabulated and analysed using SPSS, version 16. $P<0.05$ was considered statistically significant.

\section{Results}

The age of the women in the 2 groups was similar, ranging from 15 to 18 years. Mean age was 16.33 [standard deviation (SD) 1.26] years for the study group and 16.92 (SD 1.23) years for the control group $(P=0.71)$ (Table 1). Age at marriage ranged from 14 to 18 years. Mean age at marriage was 15.33 (SD 1.19) years in the study group and 15.55 (SD 1.31) years in the control group $(P=0.42)$. There was a statistically significant difference between the 2 groups in regard to education level: $69.8 \%$ of the study group and $37.2 \%$ of the control group had less than secondary education $(P$ $=0.002)$. The recruitment visit was the first antenatal clinic visit for $76.6 \%$ of the study group and $79.1 \%$ of the control group $(P=0.79)$.

Table 2 illustrates the general health condition of our pregnant teenage participants. The mean body mass index was $28.62(\mathrm{SD}=5.04) \mathrm{kg} / \mathrm{m}^{2}$ in the study group and $30.64(\mathrm{SD}=5.17) \mathrm{kg} /$ $\mathrm{m}^{2}$ in the control group $(P=0.07)$. Also, $18.6 \%$ of the study group and $14.0 \%$ of the control group had had a previous abortion $(P=0.05)$.

The most common complaint in the study group was muscle cramps and in the control group anaemia (Table 2). Only muscle cramps, nausea and constipation differed significantly between the 2 groups.

Table 3 illustrates the knowledge about health promotion aspects among teenage pregnant women in the study and control groups before and after the counselling programme. Before the intervention, around half of the participants in each group had satisfactory knowledge with regard to nutrition but less than $50 \%$ had

\begin{tabular}{|c|c|c|c|}
\hline \multirow[t]{2}{*}{ Characteristic } & $\begin{array}{l}\text { Study group } \\
\qquad(n=43)\end{array}$ & $\begin{array}{c}\text { Control group } \\
(n=43)\end{array}$ & $P$-value \\
\hline & $\%$ & $\%$ & \\
\hline \multicolumn{4}{|l|}{ Education level } \\
\hline Less than secondary & 69.8 & 37.2 & 0.002 \\
\hline Secondary & 30.2 & 62.8 & 0.80 \\
\hline \multicolumn{4}{|l|}{ Occupation } \\
\hline Housewife & 76.7 & 74.4 & 0.80 \\
\hline Student & 23.3 & 25.6 & 0.04 \\
\hline \multicolumn{4}{|l|}{ Type offamily } \\
\hline Nuclear & 79.1 & 74.4 & 0.79 \\
\hline Extended & 20.9 & 25.6 & \\
\hline \multicolumn{4}{|c|}{ Monthly income/basic needs } \\
\hline Sufficient & 51.2 & 30.2 & 0.048 \\
\hline Insufficient & 48.8 & 69.8 & \\
\hline \multicolumn{4}{|l|}{ No. of antenatal visits } \\
\hline 1 & 76.6 & 79.1 & 0.79 \\
\hline \multirow[t]{2}{*}{2} & 23.3 & 20.9 & \\
\hline & Mean (SD) & Mean (SD) & \\
\hline Age (years) & $16.33(1.26)$ & $16.92(1.23)$ & 0.71 \\
\hline Age at marriage (years) & $15.33(1.19)$ & $15.55(1.31)$ & 0.42 \\
\hline
\end{tabular}

$S D=$ standard deviation 


\begin{tabular}{|c|c|c|c|c|c|}
\hline \multirow[t]{2}{*}{ Health parameter } & \multicolumn{2}{|c|}{$\begin{array}{l}\text { Study group } \\
\quad(n=43)\end{array}$} & \multicolumn{2}{|c|}{$\begin{array}{c}\text { Control group } \\
(n=43)\end{array}$} & \multirow[t]{2}{*}{$P$-value } \\
\hline & No & $\%$ & No & $\%$ & \\
\hline Albumin in urine & 4 & 9.3 & 6 & 14 & 0.5 \\
\hline Previous abortion & 8 & 18.6 & 6 & 14 & 0.5 \\
\hline \multicolumn{6}{|l|}{ Most common complaint } \\
\hline Muscle cramps & 30 & 69.8 & 18 & 41.9 & 0.009 \\
\hline Anaemia $(\mathrm{Hb}<11 \mathrm{~g} / \mathrm{dL})$ & 26 & 60.5 & 29 & 67.5 & 0.5 \\
\hline Nausea & 22 & 51.2 & 11 & 25.6 & 0.01 \\
\hline Haemorrhoids & 21 & 48.8 & 16 & 37.2 & 0.27 \\
\hline Heartburn & 20 & 46.5 & 14 & 32.6 & 0.18 \\
\hline Headache & 15 & 34.9 & 22 & 51.2 & 0.12 \\
\hline Shortness of breath & 7 & 16.3 & 12 & 27.9 & 0.19 \\
\hline \multirow[t]{2}{*}{ Constipation } & 4 & 9.3 & 14 & 32.6 & 0.008 \\
\hline & \multicolumn{2}{|c|}{ Mean (SD) } & \multicolumn{2}{|c|}{ Mean (SD) } & \\
\hline BMI $\left(\mathrm{kg} / \mathrm{m}^{2}\right)$ & \multicolumn{2}{|c|}{$28.62(5.04)$} & \multicolumn{2}{|c|}{$30.64(5.17)$} & 0.07 \\
\hline Haemoglobin & \multicolumn{2}{|c|}{$10.86(1.06)$} & \multicolumn{2}{|c|}{$10.28(1.11)$} & 0.7 \\
\hline
\end{tabular}

$B M I=$ body mass index $; S D=$ standard deviation .

satisfactory knowledge regarding the other items, with exercise being the lowest (Table 3). Before the programme, there was no statistically significant difference for knowledge between the 2 groups. After the programme there was a great improvement in health promotion knowledge in the study group but not in the control group, with a statistically significant difference between the 2 groups for all items $(P<0.001)$.

Table 4 describes the adequacy of compliance with certain aspects of health promotion in the study and control groups. At the pre-test, no statistically significant differences were present between the study and control groups as regards compliance to certain aspects of health promotion. At the post-test, after the counselling programme, the study group had statistically significantly better compliance compared to the women in the control group $(P<0.001)$ except for compliance to medication use.

Only 4 of the babies born to mothers in the study group were pre-term (< 38 weeks) while 18 of the mothers in the control group had pre-term babies

\begin{tabular}{|c|c|c|c|c|c|c|}
\hline \multirow[t]{3}{*}{ Item } & \multicolumn{6}{|c|}{ Satisfactory knowledge (\%) } \\
\hline & \multicolumn{3}{|c|}{ Pre-counselling } & \multicolumn{3}{|c|}{ Post-counselling } \\
\hline & $\begin{array}{l}\text { Study group } \\
\quad(n=43)\end{array}$ & $\begin{array}{l}\text { Control group } \\
\qquad(n=43)\end{array}$ & $P$-value & $\begin{array}{l}\text { Study group } \\
\quad(n=43)\end{array}$ & $\begin{array}{l}\text { Control group } \\
\qquad(n=43)\end{array}$ & $P$-value \\
\hline Nutrition & 51.2 & 46.5 & 0.66 & 93.0 & 44.2 & $<0.001$ \\
\hline Smoking & 46.5 & 37.2 & 0.38 & 95.3 & 55.8 & $<0.001$ \\
\hline Clothing & 46.5 & 32.6 & 0.18 & 93.0 & 37.2 & $<0.001$ \\
\hline Ante-natal follow-up & 44.2 & 23.3 & 0.04 & 93.0 & 23.3 & $<0.001$ \\
\hline Rest \& activity & 44.2 & 39.5 & 0.66 & 95.3 & 39.5 & $<0.001$ \\
\hline Travelling & 44.2 & 37.2 & 0.51 & 97.7 & 37.2 & $<0.001$ \\
\hline Medication use & 41.9 & 20.9 & 0.03 & 93.0 & 32.6 & $<0.001$ \\
\hline Danger signs & 37.2 & 39.5 & 0.8 & 100.0 & 37.2 & $<0.001$ \\
\hline Minor discomfort & 37.2 & 39.5 & 0.8 & 83.7 & 39.5 & $<0.001$ \\
\hline Immunization & 37.2 & 41.9 & 0.6 & 100.0 & 48.8 & $<0.001$ \\
\hline Hygiene & 32.6 & 37.2 & 0.65 & 83.7 & 53.5 & 0.003 \\
\hline Exercise & 23.3 & 18.6 & 0.26 & 95.3 & 30.2 & $<0.001$ \\
\hline
\end{tabular}




\begin{tabular}{|c|c|c|c|c|c|c|}
\hline \multirow[t]{3}{*}{ Parameter } & \multicolumn{3}{|c|}{ Pre (adequate compliance) } & \multicolumn{3}{|c|}{ Post (adequate compliance) } \\
\hline & Study & Control & $P$-value & Study & Control & $P$-value \\
\hline & $\%$ & $\%$ & & $\%$ & $\%$ & \\
\hline Antenatal follow-up & 14.0 & 20.9 & 0.3 & 95.3 & 16.3 & $<0.001$ \\
\hline Nutrition & 20.9 & 16.3 & 0.57 & 90.7 & 16.3 & $<0.001$ \\
\hline Exercise & 0.0 & 0.0 & - & 60.5 & 9.3 & $<0.001$ \\
\hline Hygiene & 39.5 & 46.5 & 0.51 & 100.0 & 41.9 & $<0.001$ \\
\hline Rest \& activity & 48.8 & 32.6 & 0.12 & 74.4 & 44.2 & 0.004 \\
\hline Immunization & 53.5 & 44.2 & 0.38 & 100.0 & 60.5 & $<0.001$ \\
\hline Smoking & 23.3 & 16.3 & 0.41 & 100.0 & 16.3 & $<0.001$ \\
\hline Medication use & 55.8 & 51.2 & 0.66 & 76.7 & 72.1 & 0.24 \\
\hline Travelling & 32.6 & 37.2 & 0.65 & 100.0 & 44.2 & $<0.001$ \\
\hline Clothing & 44.2 & 55.8 & 0.28 & 100.0 & 51.2 & $<0.001$ \\
\hline
\end{tabular}

$(P=0.001)($ Table 5). There was a statistically significant difference between the study and control groups regarding occurrence of complications during labour $(P=0.003)$.

There were also statistically significant differences in regard to the general health of the babies in the 2 groups: 30 of the 43 mothers in the study group had babies with good general health compared with only 20 of the 43 mothers in the control group $(P<0.001)$ (Table 5); 4 of the babies in this group were stillborn.

Birth weight (low/normal), breast feeding (exclusive/not exclusive/artificial) and the condition of the umbilicus (clean/septic/bloody) also showed statistically significant differences between the 2 groups (Table 5 ).

\section{Discussion}

Although the legal age for marriage in Egypt at the time of our study was 16 years for females and 18 years for males, the mean age at marriage of the pregnant women in our study was 15.33 years for the study group and 15.55 years for the control group, indicating that under-age marriage is still a concern. A recent study on teenage mothers in India showed similar results. Although the legal age for marriage is 18 years for females and 21 years for males in India, early marriage is common [15]; by age 15 years, $26 \%$ of females are married.

As is usual in Egyptian culture, all the teenage pregnant women in our study were married and received support from their families. Also, fertility is highly valued: reproduction is encouraged by religious and social beliefs and the wife has higher self-esteem after having children.

More than $70 \%$ of our participants had made only 1 visit to the antenatal care clinic. Similarly, antenatal care services in Indonesia are still underutilized. Approximately $95 \%$ of pregnant women in Indonesia attended at least 1 antenatal care visit, but only $66 \%$ had made the recommended 4 visits [16].

The prevalence of anaemia in the study and control groups was quite high, over 60\%. In developing countries over $50 \%$ of pregnant women suffer from iron deficiency anaemia [17]. It is also prevalent among adolescent girls because the growth spurt and onset of menstruation increase iron requirements. Iron supplementation during adolescence is one of the strategies advocated to improve iron balance in pregnancy [18].

Our findings indicated a deficit in knowledge and compliance with health promotion actions in the 2 groups. After the programme, an improvement was noted in the study group but not the control group. Education about the importance of good nutrition before and during pregnancy should be given to adolescents, including information about the obstetric complications resulting from poor nutritional status in pregnancy. Nutritional deficiencies in pregnancy have been found to contribute to poor maternal outcomes $[19,20]$. This is supported by Reron et al., who suggest that pregnant women do not make significant changes in their nutrition habits because they are insufficiently informed about the importance of a healthy diet during pregnancy [21].

In a study of lifestyle practices of Jordanian pregnant women, it was found that the physical activity behaviour, which measures the women's ability to follow a regular exercise pattern, was ranked last among the health-promoting lifestyle behaviours [13]. Our participants also showed little knowledge of the benefits of exercise pre-counselling. In the study group however, after counselling, over $95 \%$ of the women demonstrated satisfactory knowledge.

Our findings were in accordance with those of Maimbola, Ahmed and Ransjo-Arvidson, who stated that health promotion is an essential component 


\begin{tabular}{|c|c|c|c|c|c|}
\hline \multirow[t]{2}{*}{ Parameter } & \multicolumn{2}{|c|}{$\begin{array}{l}\text { Study group } \\
\quad(n=43)\end{array}$} & \multicolumn{2}{|c|}{$\begin{array}{l}\text { Control group } \\
\qquad(n=43)\end{array}$} & \multirow[t]{2}{*}{$P$-value } \\
\hline & No. & $\%$ & No & $\%$ & \\
\hline Gestational age at labour & & & & & 0.001 \\
\hline At term (38-42 weeks) & 39 & 90.7 & 25 & 58.1 & \\
\hline Pre-term $(<38$ weeks $)$ & 4 & 9.3 & 18 & 41.9 & \\
\hline \multicolumn{6}{|l|}{ Type of delivery } \\
\hline Normal vaginal & 38 & 88.4 & 33 & 76.7 & \multirow[t]{2}{*}{0.15} \\
\hline Caesarean section & 5 & 11.6 & 10 & 23.3 & \\
\hline Complications during labour & 5 & 11.6 & 17 & 39.5 & 0.003 \\
\hline Obstructed labour & 2 & 4.7 & 8 & 18.6 & 0.04 \\
\hline Vaginal bleeding & 2 & 4.7 & 5 & 11.6 & $0.43^{\mathrm{a}}$ \\
\hline Tears of perineum & 1 & 2.3 & 4 & 9.3 & 0.35 \\
\hline Pregnancy outcome & & & & & 0.006 \\
\hline Full-term baby & 39 & 88.4 & 25 & 58.1 & \\
\hline Pre-term baby & 4 & 9.3 & 12 & 27.9 & \\
\hline \multicolumn{6}{|l|}{ General condition of baby } \\
\hline Good & 39 & 90.7 & 20 & 46.5 & $<0.001$ \\
\hline Bad & 4 & 9.3 & 19 & 44.2 & $<0.001$ \\
\hline Dead & 0 & 0 & 4 & 9.3 & $0.12^{\mathrm{a}}$ \\
\hline \multicolumn{6}{|l|}{ Birth weight } \\
\hline $\operatorname{Low}(<2.5 \mathrm{~kg})$ & 4 & 9.3 & 14 & 32.6 & \multirow{2}{*}{0.008} \\
\hline Normal (2.5-3.5 kg) & 39 & 90.7 & 29 & 67.4 & \\
\hline \multicolumn{6}{|l|}{ Breastfeeding } \\
\hline Exclusive & 35 & 81.4 & 16 & 37.2 & $<0.001$ \\
\hline Not exclusive & 6 & 14 & 23 & 53.5 & $<0.001$ \\
\hline Artificial & 2 & 4.7 & 4 & 9.3 & $0.67^{a}$ \\
\hline \multicolumn{6}{|l|}{ Umbilicus } \\
\hline Septic & 4 & 9.3 & 18 & 41.9 & $<0.001$ \\
\hline Clean & 36 & 83.7 & 16 & 37.2 & $<0.001$ \\
\hline Blood & 3 & 7 & 9 & 20.9 & 0.06 \\
\hline
\end{tabular}

${ }^{a}$ Yates corrected $\chi^{2}$.

of antenatal care: it provides the opportunity for the individual pregnant adolescent mother to discuss her health, pregnancy, labour and plans for childbearing and child care [22]. Counselling on health promotion and disease prevention and cure is a fundamental part of any medical consultation. It has a direct impact on patient health and an overall impact on the burden of disease in the community [23].

Our data confirm the findings of other investigators who indicated that antenatal care provides an opportunity to educate the pregnant woman about pregnancy and childbirth [24]. Antenatal education programmes are a very important component of antenatal care worldwide since they encourage women themselves contribute for a better pregnancy outcome and care of the neonate $[25,26]$.

We found that pregnancy outcomes were better in the study group compared with the control group. This agreed with the findings of other studies which found rates of stillbirths to average about 50\% higher for adolescent mothers compared with mothers in their 20s [27]. Too-early childbearing also has a negative impact on the survival of babies. A large American study found a $55 \%$ greater risk of neonatal death in babies of mothers aged 10-15 years, a 19\% higher risk in babies of 16-17-year-olds, and a $6 \%$ higher risk in babies of 18-19-year-olds [28]. A study in Latin America found a 50\% greater risk of neonatal death in babies of mothers aged under 16 years [29]. Large national surveys show neonatal death risk levels are typically $50 \%-100 \%$ higher in babies of adolescents compared with those of older women [30]. Studies have shown an independent 
adverse effect of early pregnancy on newborn health conditions such as preterm birth, low birth weight, small for gestational age, asphyxia and malformations [2]. Flynn, Budd and Modelski concluded that pregnant adolescents are a very vulnerable population, experiencing disproportionately high rates of adverse birth outcomes [31]. In a review of 14 studies, Coren, Barlow and Stewart-Brown concluded that educational interventions can have a positive impact on outcomes for this vulnerable group [32].

In agreement with our findings, Grady and Bloom found that a positive, supportive prenatal health experience may encourage and empower adolescents to care for themselves and their children [33]. Some research on teenage pregnancy has indicated that with good psychosocial support and appropriate and adequate prenatal care, teenagers could have similar pregnancy outcome to that of older women $[34,35]$.

In this study we have demonstrated that prenatal health education is an important and successful strategy for reducing health disparities for women who are members of a vulnerable population. This is supported in other research [11]. Prenatal health education should be an integral part of prenatal care as a means of improving the perinatal outcomes for women and their infants.

\section{References}

1. Nash ES. Teenage pregnancy-need a child bear a child? South African Medical Journal, 1990, 77:147.

2. Position paper on mainstreaming adolescent pregnancy in efforts to make pregnancy safer. Geneva, World Health Organization, Making Pregnancy Safer, 2010.

3. Ibrahim SE, Ibrahim BL. Egypt's population policy: the long march of state and civil society. In: Jain A, ed. Do population policies matter? Fertility and politics in Egypt, India, Kenya and Mexico. New York, Population Council, 1998.

4. Tsai YF, Wong TK. Strategies for resolving aboriginal adolescent pregnancy in eastern Taiwan. Journal of Advanced Nursing, 2003, 41(4):351-357.

5. Allender JA, Spradley BW. Community health nursing: promoting and protecting the public's health, 6th ed. Philadelphia, JB Lippincott Co, 2005:654-655.

6. Department of Health. Saving lives: our healthier nation. London, The Stationery Office, 1999.

7. Nichols M, Roux G, Harris N. Primigravid and multigravid women: prenatal perspectives. Journal of Perinatal Education, 2007, 16(2):21-32.

8. Enriquez M et al. Pregnancy, poverty, and HIV. Journal of Nurse Practitioners, 2007, 3(10):687-93.

9. Risica PM, Phipps MG. Educational preferences in a prenatal clinic population. International Journal of Childbirth Education, 2006, 21(4):4-7.

10. Stanhope M, Lancaster J. Foundations of Nursing in the Community, Community Oriented Practice. 3rd ed. Philadelphia, Mosby, 2008.

11. Vonderheid SC, Norr K F, Handler AS. Prenatal health promotion content and health behaviors. Western Journal of Nursing Research, 2007, 29(3):258-276.

12. Aminoff $\mathrm{U}$, Kjellgren $\mathrm{K}$. The Nurse Source in Hypertension Care. Journal of Advanced Nursing, 2002, 35(4):582.

13. Gharaibeh M, AL-Ma'aitah R, AL Jada N. Lifestyle practices of Jordanian pregnant women. International Nursing Review, 2005, 52:92-100.

14. Patterson ET, Freese MP, Goldenberg RL. Seeking safe passage; utilizing health care during pregnancy. Nursing Image, 1990, 22:27-31.

15. Mukhopadhyay P, Chaudhuri RN, Paul B. Hospital-based perinatal outcomes and complications in teenage pregnancy in India. Journal of Health, Population \& Nutrition, 2010, 28(5):494-500.

16. Indonesia Demographic and Health Survey 2070. Calverton, Maryland, Badan Pusat Statistik, National Family Planning
Coordinating Board, Ministry of Health and ORC Macro, 2008.

17. Lynch SR. The potential impact of iron supplementation during adolescence on iron status in pregnancy. Journal of Nutrition, 2000, 130(2 Suppl.):448s-451s.

18. Kalanda BF, Verhoeff $\mathrm{FH}$, Brabin BJ. Chronic malnutrition in pregnant adolescents in rural Malawi: an anthropometric study. Acta Obstetricia et Gynecologica Scandinavica, 2006, 85(1):33-39.

19. Demir S, Balci E, Günay O. Comparison of life quality of pregnant adolescents with that of pregnant adults in Turkey. Upsala Journal of Medical Sciences, 2010, 115:275-281.

20. Reynolds HW, Wong EL, Tucker H. Adolescents' use of maternal and child health services in developing countries. International Family Planning Perspectives, 2006, 32(1):6.

21. Reron A et al. Nawyki zywieniowe kobiet ciezarnych [Nutrition habits in pregnant women]. Przeglad lekarski, 2003, 60(Suppl. 6):8-11.

22. Maimbola M, Ahmed $Y$, Ransjo-Arvidson AB. Safe motherhood perspectives and social support for primigravidae women in Lusaka, Zambia. Social Science \& Medicine, 2003, 58(11):34.

23. Ahsen F et al. Developing counseling skills through prerecorded videos and role play: a pre- and post-intervention study in a Pakistani medical school, BMC Medical Education, 2010, 10:7.

24. Haggaz AA, Radi EA, Adam I. High maternal mortality in Darfur, Sudan. International Journal of Gynaecology \& Obstetrics, 2007, 98:252-253.

25. Renkert S, Nutbeam D. Opportunities to improve maternal health literacy through antenatal education: an exploratory study. Health Promotion International, 2001, 16:381-388.

26. Turan JM, Sale L. Community base antenatal education in Istanbul, Turkey: effects on health behaviours. Health Policy and Planning, 2003, 18(4):391-398.

27. Position paper on mainstreaming adolescent pregnancy in efforts to make pregnancy safer. Geneva, World Health Organization, Department of Making Pregnancy Safer, 2010 (WHO/MPS/10.03).

28. Salihu HM et al. Childhood pregnancy (10-14 years old) and risk of stillbirth in singletons and twins. Journal of Pediatrics, 2006, 148(4):522-526.

29. Conde-Agudelo A, Belizan JM, Lammers C. Maternal-perinatal morbidity and mortality associated with adolescent pregnancy in Latin America: Cross-sectional study. American Journal of Obstetrics \& Gynecology, 2005, 192(2):342-349. 
30. Chen XK et al. Teenage pregnancy and adverse birth outcomes: a large population based retrospective cohort study. International Journal of Epidemiology, 2007, 36(2):368-373.

31. Flynn L, Budd M, Modelski J. Enhancing resource utilization among pregnant adolescents. Public Health Nursing, 2008, 25(2):140-148.

32. Coren E, Barlow J, Stewart-Brown S. The effectiveness of individual and group-based parenting programmes in improving outcomes for teenage mothers and their children: a systematic review. Journal of Adolescence, 2003, 26:79-103.
33. Grady M, Bloom K. Pregnancy outcomes of adolescents enrolled in a centering pregnancy program. Journal of Midwifery \& Women's Health, 2004, 49(5):412.

34. Mahfouz AR et al. Teenage pregnancy: are teenagers a high risk group? European Journal of Obstetrics, Gynecology \& Reproductive Biology, 1995, 59:17-20.

35. Lao TT, Ho LF. The obstetric implications of teenage pregnancy. Human Reproduction, 1997, 12(10):2303-2305.

\section{Saving the lives of mothers and children in the Region}

Addressing the health of mothers and children is at the heart of the Millennium Development Goals (MDGs) and health and development index. It is the subject and focus of several United Nations and WHO resolutions adopted by all Member States.

To reduce mortality among mothers and children, the World Health Organization (WHO), United Nations Children's Fund (UNICEF) and the United Nations Population Fund have jointly organized a high-level meeting "Saving the lives of mothers and children: accelerating progress towards achieving MDGs 4 and 5 in the Region". The meeting will take place in Dubai, United Arab Emirates, from 29 to 30 January 2013, under the patronage of Her Royal Highness Princess Haya Bint Al Hussein, wife of His Highness Sheikh Mohammed Bin Rashid Al Maktoum, Vice-President and Prime Minister of the United Arab Emirates and Ruler of Dubai. The high-level meeting will be in the form of a global forum featuring unique partnerships to address the increase in mother and child mortality rates in the Eastern Mediterranean Region.

Further information about the work of WHO in the Region to improve the health of mothers and children can be found at: www.emro.who.int/health-topics/child-health-and-development/ and www.emro.who.int/entity/rhrn/ 